\title{
Effect of Educational Program on Knowledge and Uses of Social Network Sites of Faculty of Nursing Students at Tanta University Sara Mohamed Ahmed El-Gamal ${ }^{1}$, Nahed Karam Mahmoud Elsehry ${ }^{2}$ \\ ${ }^{1,2}$ Lecturer of Community Health Nursing, Faculty of Nursing, Tanta University, Tanta,
} Egypt.

\begin{abstract}
Background: Now a day, social network sites among students become most common. There are different and more advancing types of social network sites and have greater impact on the way the people use of it and have remained major public health issues throughout the whole world. The aim of the study was to evaluate the effect of an educational program on knowledge and uses of social network of students on faculty of nursing at Tanta University. Subjects and Method: A quasi-experimental research design was utilized in this study and it was carried out at Faculty of Nursing, Tanta University. Subjects: The total studied sample was 79 students. Tools of the study: Two tools were used for data collection; tool I: Structured interview schedule consisted of three parts. Tool II: uses of social network sites, this tool was taken and adapted from the instrument developed by Gupta and Bashir in 2018. Results: Total knowledge and uses scores were significantly improved from preprogram to three months after program application for the studied sample, where the mean of total knowledge score increased from 9.25 pre program to 13.39 three months post program and the mean of total uses score increased from 31.47 pre program to 38.54 three months post program Conclusion: The levels of knowledge and uses of the studied sample toward social network were improved after implementation of the educational program. Recommendation: Conducting lectures, workshops and campaigns to raise awareness about correct and accurate information of social network sites and its uses among other students and all community groups.
\end{abstract}

Key words: Social networking, Community health nursing students. 


\section{Introduction}

The rapid advancement of social network sites (SNS) has confirmed that, the world is small and within the reach of all people. As it provide people with more, fastest and easiest information. This may be as a result of changing in the interactive learning and sharing environment. Nowadays, classroom is lacking, and the focus become more and more on SNS in nursing education. These provide students with wider opportunity to communicate and interact with each other inside and outside the classroom ${ }^{(1-3)}$.

Social network sites have become the most popular form of online conversation where persons can develop new content, share it and make reference for it at higher level. Due to social network sites invention, the online world has changed dramatically. Now, not only the youth use social network sites at higher rate in exchange information either personal or scientific, pictures, ideas, feelings and videos but also all age group as elderly and children as well. Now about $73 \%$ of wired American teens use social media websites ${ }^{(4,5)}$.

Social networking sites (SNSs), there is no clear definition of it and alternatively used the term 'social media', because of the different language used in defining them in practice and academia. There are normal terms used for online interaction.
Distinguished SNSs on three features, first; a setup of profile either public or semipublic, second; build a connection for different users within the system, and third; explain and show connections made by others in the system, as well as one's own list of connections ${ }^{(6,7)}$.

In the previous years, social network sites become the most popular as it give people especially the youth different and modern methods of communication and interaction with the world and with each other. One of the most common examples for it, is the Facebook, where more than five hundred million individuals are used it and approximately $85 \%$ of them are undergraduate students ${ }^{(8)}$.

These numbers of Facebook users are increased and every new day this numbers increases and in continuous grow. You Tube users are also increases. The increasing uses of social network sites affects greatly on ordinary social relationship and communication and make the world more technologically ${ }^{(9,10)}$.

Communicating in person- to- person situation is quite different from communicating through the internet and SNS. Through these websites immediate, rapid message and chatting as well as updating the status are used as a way of communication. It is obvious that SNS 
affect the way of receiving information and news. These sites have numerous and various portals through which persons get information and create more different news outlets ${ }^{(11,12)}$.

Experts have recommended 30 minutes or less per day as the maximum time a person should spend on social media ${ }^{(13)}$. It can be used on academic education to solve academic problem, research work, for online academic group discussion, for collaborative learning. Also, it can be used for Socialization, Entertainments and informativeness. Social media has greater effect on every different aspect of life and work nowadays. It is amazing that, social media grasp person's attention and concentration more rapidly without awareness of people. Social media has expensive and greater advantages on education, occupation and investment and on other fields of life. On the opposite it is also has unhealthy and destructive effect on the individuals if they don't use correctly $\left({ }^{14,15)}\right.$.

Internet addiction is another worst disadvantage of social network sites as persons spend too much time using it throughout the day and the night with denial to essential responsibilities. It is normally that their performance in different sides of life as in education and work will badly affected as a result of miss using social network sites. In addition to that, students' losses their motivational level as they depend largely on social media as it provides easiest and fastest information. Therefore, students become less interested to actual practical learning environment and instead they focus more greatly in virtual learning environment. At the end, research and learning capabilities of students reduced as a result of misusing it $^{(16,17)}$.

Mental and physical problems are other examples of bad effect of misusing to social network sites on individuals. Disintegration of the family is considered another bad effect of social network sites as individuals' losses family social relation skills and instead focus on using social media and every individual in the family become has separate life that grasp them away from their family interests. Cyber bullying, is one of SNS major issue these days. Some examples of these are publicly harassing, posting mean comments, spread unreliable and false information ${ }^{(19,20)}$.

\section{Significant of the study}

Today the rapid advancement of social media, provide people with different methods of communication. Over the years, SNS among students has become more and more popular. It is a way of interaction and connections among students either in the school or outside it. 
As a result of increased its popularly, professors and experts are wondering whether students achievements and grades will not be affected by time spent on these sites. They believe that the use of social network sites may affect positively or negatively on educational performance of students. So that, the community health nurse plays an important role in assessment of students` knowledge about social network sites, provides them with suitable information about available social network sites, teaching them the proper uses, correct and suitable duration of time for using social network sites ${ }^{(19,20)}$. Therefore, this study aims to evaluate the effect of educational program on knowledge and uses of social network sites among community health nursing students on Faculty of Nursing at Tanta University.

\section{Aim of the study}

Evaluate the effect of educational program on knowledge and uses of social network sites of students on Faculty of Nursing at Tanta University.

\section{Research Hypothesis}

Knowledgeand uses of social network sites among community health nursing students on Faculty of Nursing at Tanta University expected to be improved after implementation of educational program.

\section{Subjects and Method}

\section{Deign}

A quasi experimental (pre-post) research design was utilized in this study.

\section{Study setting}

The study was conducted in Faculty of Nursing, Tanta University.

\section{Subjects}

The sample size was calculated using Epiinfo 7 software program. The criteria for sample size selection were determined at 95\% confidence limit, study power $80 \%$ with a $5 \%$ margin of error. The calculated sample size was found to be 51 students and to be increased to 79 to increase the validity of the results.Seventy nine community health nursing students were included in the study. Systematic random sampling was used, where a list of names and numbers of all community health nursing students was obtained and it was about (170 students) then divided by the recommended sample size (79 students) to determine the interval of choosing sample and it was equal to 2. (Total population/ sample $=$ interval $)(170 / 79=2.1)$. the starting point of selecting the sample was number one selected by simple random sampling then every time increase two numbers to be as follow $(1,3,5,7, \ldots \ldots \ldots)$ 
until attaining the recommended sample size of 79 students of community health nursing).

\section{Tools of the study:}

In order to collect the necessary data, the following two tools were used.

Tool I: A structured interview schedule: It included the following parts:-

\section{Part (1): Socio-demographic} characteristics of community health nursing students: Which include data about: age, sex, grade of education, place of residence and family income.

\section{Part (2): History of using social network} sites

Which include data about pattern of using social network sites such as: usage, usage in education, duration of usage, daily time of usage, and the most frequently used social network sites.

\section{Part (3) knowledge of community health} nursing students about social network sites ${ }^{(6-10,13-16)}$ :

This part developed by the researcher to evaluate nursing students' knowledge about social network sites. It included: definition, causes of use, types, benefits and harms of using social network sites.

The scoring system: The items of the questionnaire were checked with a model key answer, which were prepared by the researcher. A score one was given for each correct point of answer while a zero score for incorrect answer and don't know.

The knowledge total score was calculated by summation of the score of all items of knowledge about social network sites and it equaled 20 points. The total amount of score summation of each student were divided by maximum score of knowledge and multiplied by 100 to get the total score percentage.

The scoring system of knowledge was as follow:-

- Poor knowledge: a scoring of $<50 \%$ of the total score ( $<10$ points).

- Fair knowledge: a scoring of $50<70$ $\%$ of the total score (10 to $<14$ points).

- Good knowledge: a scoring of $\geq 70 \%$ of the total score ( $\geq 14$ points).

\section{Tool II: Uses of social network sites ${ }^{(21)}$}

This tool was taken and adapted from the instrument developed by Gupta and Bashir in $2018 \mathrm{n}^{(21)}$. It was used to assess usage of social network sites by community health nursing students. It assesses five dimensions of usage of social network sites. Dimension one Academicwhich includes 7 items. Dimension two socialization which includes 6 items. Dimension three Entertainments which include 4 items. Dimension four in formativeness which includes 3 items.Dimension five constraints which include 4items. 


\section{The scoring system for usage of social} network sites:

- It was made using a 3-point LikertScale, a zero (0) score for the items which that wasn't agreed, one score for the items that was neutral and two score for the items that was agreed by community health nursing students except for dimension five constraints especially for items (1and 3) in these items the disagreed items were given score two and agreed items were given score zero. These scores were summed up and the total score equal 48 points then converted into a percent score.

The scoring system for usage of social network sites was classified into:

- Poor usage: a scoring of $<50 \%$ of the total score $(<24$ points).

- Moderate usage: a scoring of $50<70$ $\%$ of the total score (24 to $<34$ points).

- Good usage: a scoring of $\geq 70 \%$ of the total score ( $\geq 34$ points).

\section{Method}

\section{Ethical considerations}

- Before conducting the study, permission obtained from the Dean of Faculty of Nursing, Tanta Universityand the head of community health nursing department.

- An informed oral agreement was obtained. Rightsand confidentiality of the students were respected in all phases of the study and the study not cause any harm to the students.

2. Developing tools: Tool I was developed by the researchers based on reviewing of current related literature and tool two was adapted from the instrument developed by Gupta s and Bashir 1 in 2018.

3. Validity of the tools: The study tools were tested for its validity by five expertise from the community health nursing department.

4. Cronbach's Alpha test was used to test their liabilityof the study tools and it was computed and was found to be 0.822 for all the study tools.

5. A pilot study was carried out on $10 \%$ (about 8 students) of the students.

6. The study was conducted in four phases as follow:

I. Phase one: - Assessment phase :(pretest) - The data was collected by the previously mentioned tools through giving each studied subject questionnaire to collect the baseline data as a preintervention assessment.

II. Phase two: - Educational program development. An educational program was developed based on the results of phase one that determines the studied students' needs and recent relevant literature review. 
III. Phase three: An educational program implementation.

The educational program content was implemented on 4 sessions. The educational program sessions were carried out with the duration of each session approximately 30- 45 minutes. The educational program was conducted by using group discussion with the studied community health nursing students, answering their questions and providing explanation. Teaching materials were included power point presentation, videos, and posters. The handout was distributed on the studied community health nursing students. It was written in a simple language and supplemented by photos and illustrations to help the studied community health nursing students in the understanding of the content simply.

\section{Session 1: Program orientation and expectation.}

The aim of this session was to orient the studied community health nursing students about the importance of the program and to assess their expectations from each session.

Session 2: An overview about social network sites. The aim of this session was to help the studied community health nursing students to define social media, discuss importance, select actual and suitable duration of times for using social media.

Session 3: Types of social network sites, advantage and disadvantage. The aim of this session was to help the studied community health nursing students to identify the available social network sites, differentiate between advantage and disadvantage of social network sites.

Session 4: uses of social network sites. The aim of this session was to help community health nursing students to discuss different uses of social network sites and to evaluate its impact on academic, entertainment, informativeness and socialization.

IV. Phase four: Educational program evaluation. The aim of this phase was to determine the effectiveness of the educational intervention. This was done by reapplying the tools (tool I part IV, and tool II) through interviewing the subjects twice: -

-First time: Before implementation of the intervention (pretest).

-Second time: Three months after the implementation of the intervention.

7. The actual data collection was started from October 2020 to January 2021. The researchers met the study subjects in the community health nursing department in the faculty of nursing two days per week. 


\section{Statistical analysis}

Using SPSS (version 23).For quantitative data, range, mean, and standard deviation were calculated. For comparison between means of two parametric variables student t-test was used. For qualitative data, comparison was done using chi-square. Spearman's correlation coefficient was used for evaluation between variables of the study. A significant was adopted at $\mathrm{P}$ value $<0.05$ for interpretation of results of significance. High significance was adopted at $\mathrm{P}$ value $<0.01$

\section{Results}

Table (1) shows socio-demographic characteristics of the studied community health nursing students. It reveals that, slightly more than half of the studied community health nursing students $(52.5 \%)$ their age ranged from 21 to $<22$ with a mean of $21.54 \pm 0.636$ and the majority of them $(93.7 \% \& 89.9 \%)$ were female and their family income were enough respectively. In addition to, more than two- thirds of them $(67.1 \%)$ were livings in rural areas.

Table (2) shows history of using social network sites of the studied community health nursing students. It reveals that the majority of the studied community health nursing students (96.2\% \& 92.4\%) were using social network sites and WhatsApp was the most frequently used method respectively. More than threequarters of them $(78.5 \%)$ were using social network sites for studying and about onethird $(31.6 \%)$ were using social networking sites for more than 5 years and were spending from $1<2$ hours on social networks daily.

Table (3)shows knowledge of the studied community health nursing students about social network sites preprogram and three months post program intervention. It was observed that there was a significant improvement of the knowledge of the studied community health nursing students regarding meaning, causes, positive effect, negative effect, advantages and dis advantages of using social network sites from preprogram to three months post program intervention.

Furthermore, the total knowledge score of the studied community health nursing students was improved from preprogram to three months post program intervention, where the mean score of their knowledge increased from 9.25 3.111 during preprogram to $13.39 \pm 3.356$ three months post program intervention with a statistically significant difference $(t=7.149$, $\mathrm{p}=0.001)$.

Table (4)shows levels of usage of social network sites by the studied community health nursing students from pre and three months post program 
intervention. It reveals that more than three quarters $(77.2 \%)$ of the studied community health nursing students had a good usage score of social network sites during three- months post program compared to $36.2 \%$ during preprogram intervention. On the other hand, about $(13.9 \%)$ had poor usage score during preprogram and this percentage decreased to $(2.5 \%)$ during three- months post program intervention.

There was a significant improvement of the total usage score of social network sites by the studied community health nursing students from preprogram to three- months post program intervention, where the mean

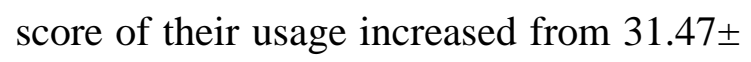
7.979 during preprogram to $38.54 \pm 7.148$ three- months post program intervention with a statistically significant difference $(\mathrm{t}=5.841, \mathrm{p}=0.001)$

Table (5) represents the correlation between total knowledge score and total usage score of social network sites among the studied community health nursing students preprogram and three months post program intervention. It reveals that there was a significant negative correlation between total knowledge score pre and three-months post program intervention $(\mathrm{p}=0.018)$. While, total knowledge score preprogram was a positively correlated with total usage score of social network sites preprogram $(\mathrm{p}=$ 0.025). Moreover, post total knowledge score was a positively correlated with post total usage score $(p=$ 0.000 )

Table (6) represents the relationship between levels of knowledge of social network sites of the studied community health nursing students during preprogram intervention and history of using social network sites. It reveals that there was statistically significant difference between hours spends on social network sites daily by community health nursing students and levels of knowledge preprogram. While there was no statistically significant difference found between period of using social networking sites by community health nursing students and levels of knowledge preprogram.

Table (7) represents the relationship between levels of usage of social network sites by the studied community health nursing students during preprogram intervention and history of using social network sites. It reveals that there was statistically significant difference between hours spends on social network sites daily by community health nursing students and levels of usage of it preprogram. While there was no statistically significant difference found betweenperiod of using social networking sites by community 
health nursing students and levels of usage

of it preprogram.

Figure (1)shows levels of knowledge of the studied community health nursing students about social network sites pre and three months post program intervention. It reveals that more than two thirds $(68.4 \%)$ of the studied community health nursing students had a good knowledge score during three months post program compared to $(15.2 \%)$ during preprogram intervention. On the other hand, about two -thirds of them (64.6\%) had a poor knowledge score during preprogram and this percentage decreased to $(17.7 \%)$ during three months post program intervention. 
Table (1):Socio-demographic characteristics of the studied community health nursing students

\begin{tabular}{|c|c|c|}
\hline \multirow{2}{*}{$\begin{array}{l}\text { Socio-demographic } \\
\text { characteristics of the studied } \\
\text { community health nursing } \\
\text { students }\end{array}$} & \multicolumn{2}{|c|}{$\begin{array}{l}\text { The studied community health nursing } \\
\text { students }(\mathrm{n}=79)\end{array}$} \\
\hline & $\mathbf{n}$ & $\%$ \\
\hline $\begin{array}{l}\text { Age } \\
21<22 \\
22 \leq 23\end{array}$ & $\begin{array}{l}42 \\
37\end{array}$ & $\begin{array}{l}52.5 \\
47.5\end{array}$ \\
\hline Range & \multicolumn{2}{|c|}{$21-23$} \\
\hline Mean \pm SD & \multicolumn{2}{|c|}{$21.54 \pm 0.636$} \\
\hline $\begin{array}{l}\text { Sex } \\
\text { Male } \\
\text { Female }\end{array}$ & $\begin{array}{c}5 \\
74\end{array}$ & $\begin{array}{c}6.3 \\
93.7\end{array}$ \\
\hline $\begin{array}{l}\text { Place of residence } \\
\text { Urban } \\
\text { Rural }\end{array}$ & $\begin{array}{l}26 \\
53\end{array}$ & $\begin{array}{l}32.9 \\
67.1\end{array}$ \\
\hline $\begin{array}{l}\text { Family income } \\
\text { Not enough } \\
\text { Enough }\end{array}$ & $\begin{array}{c}8 \\
71\end{array}$ & $\begin{array}{l}10.1 \\
89.9\end{array}$ \\
\hline
\end{tabular}


Table (2):History of using social network sites by the studied community health nursing students

\begin{tabular}{|c|c|c|}
\hline \multirow[t]{2}{*}{$\begin{array}{l}\text { History of using social network sites by the studied } \\
\text { community health nursing students }\end{array}$} & \multicolumn{2}{|c|}{$\begin{array}{l}\text { The studied community } \\
\text { health nursing students } \\
\qquad(\mathrm{n}=79)\end{array}$} \\
\hline & $\mathbf{n}$ & $\%$ \\
\hline $\begin{array}{l}\text { Use any type of social networks sites } \\
\text { Yes } \\
\text { No }\end{array}$ & $\begin{array}{c}76 \\
3\end{array}$ & $\begin{array}{c}96.2 \\
3.8\end{array}$ \\
\hline $\begin{array}{l}\text { Using social network sites for studying } \\
\text { Yes } \\
\text { No }\end{array}$ & $\begin{array}{l}62 \\
17\end{array}$ & $\begin{array}{l}78.5 \\
21.5\end{array}$ \\
\hline $\begin{array}{l}\text { Period of using social networking sites } \\
\text { Less than } 6 \text { months } \\
6 \text { month } 1<\text { year } \\
1 \text { yr-5 years } \\
\text { More than } 5 \text { years }\end{array}$ & $\begin{array}{l}17 \\
27 \\
25\end{array}$ & $\begin{array}{l}12.7 \\
21.5 \\
34.2 \\
31.6\end{array}$ \\
\hline $\begin{array}{l}\text { Hours spend on social networks sites daily } \\
1<2 \text { hours } \\
2<5 \text { hours } \\
5-8 \text { hours } \\
\text { More than } 8 \text { hours }\end{array}$ & $\begin{array}{c}25 \\
33 \\
12 \\
9\end{array}$ & $\begin{array}{l}31.6 \\
41.8 \\
15.2 \\
11.4\end{array}$ \\
\hline $\begin{array}{l}\text { \# The most frequently used type of social network } \\
\text { sites } \\
\text { WhatsApp } \\
\text { Face book } \\
\text { Telegram } \\
\text { Instagram } \\
\text { Twitter }\end{array}$ & $\begin{array}{c}63 \\
49 \\
37 \\
8\end{array}$ & $\begin{array}{c}92.4 \\
79.7 \\
62 \\
46.8 \\
10.1\end{array}$ \\
\hline
\end{tabular}




\section{(\# More than one choice)}

Table (3):Knowledge of the studied community health nursing students about social network sites preprogram and three months post program intervention

\begin{tabular}{|c|c|c|c|}
\hline \multirow{3}{*}{$\begin{array}{l}\text { Knowledge of studied community health } \\
\text { nursing students about social network } \\
\text { sites }\end{array}$} & \multicolumn{3}{|c|}{$\begin{array}{l}\text { The studied community health nursing } \\
\text { students }\end{array}$} \\
\hline & $\begin{array}{c}\text { Pre } \\
\text { intervention } \\
(\mathbf{I}) \\
(n=79)\end{array}$ & $\begin{array}{c}\text { Three months } \\
\text { post } \\
\text { intervention } \\
\text { (II) } \\
(n=79)\end{array}$ & $\mathbf{t}$ \\
\hline & Mean \pm SD & Mean \pm SD & \\
\hline Meaning of using social net worksites & $0.99 \pm 0.113$ & $1.19 \pm 0.395$ & $\begin{array}{l}.451 \\
0.001^{*}\end{array}$ \\
\hline Causes of using social network sites & $1.28 \pm 0.891$ & $2.37 \pm 0.922$ & $\begin{array}{l}6.748 \\
0.001^{*}\end{array}$ \\
\hline $\begin{array}{l}\text { Usage of social networks has any positive } \\
\text { effects on your life. }\end{array}$ & $1.92 \pm 0.781$ & $2.51 \pm 0.799$ & $\begin{array}{l}4.543 \\
0.001^{*}\end{array}$ \\
\hline $\begin{array}{l}\text { Usage of social networks has any negative } \\
\text { effects on your life. }\end{array}$ & $1.86 \pm 0.828$ & $2.23 \pm 0.715$ & $\begin{array}{l}2.998 \\
0.004^{*}\end{array}$ \\
\hline Advantages of using social networks & $1.66 \pm 1.120$ & $2.63 \pm 1.189$ & $\begin{array}{l}4.745 \\
0.001^{*}\end{array}$ \\
\hline Disadvantages of using social networks & $1.59 \pm 0.941$ & $2.48 \pm 1.011$ & $\begin{array}{l}5.432 \\
0.001^{*}\end{array}$ \\
\hline Total knowledge score & $9.25 \pm 3.111$ & $13.39 \pm 3.356$ & $\begin{array}{l}7.149 \\
0.001 *\end{array}$ \\
\hline
\end{tabular}

*Significant at $(\mathrm{p}<0.05)$ 
Table (4):Levels of usage of social network sites by the studied community health nursing students

\begin{tabular}{|c|c|c|c|c|}
\hline \multirow{3}{*}{$\begin{array}{l}\text { Levels of usage } \\
\text { of social } \\
\text { network sites }\end{array}$} & \multicolumn{4}{|c|}{ The studied community health nursing students } \\
\hline & \multicolumn{2}{|c|}{$\begin{array}{c}\text { Pre intervention } \\
\text { (I) } \\
(\mathbf{n}=79)\end{array}$} & \multicolumn{2}{|c|}{$\begin{array}{l}\text { Three months post intervention } \\
\qquad \begin{array}{c}\text { (II) } \\
(\mathbf{n}=79)\end{array}\end{array}$} \\
\hline & n & $\%$ & $\mathbf{N}$ & $\%$ \\
\hline$\overline{\text { Good use }}$ & 29 & 36.7 & 61 & 77.2 \\
\hline Moderate use & 39 & 49.4 & 16 & 20.3 \\
\hline Poor use & 11 & 13.9 & 2 & 2.5 \\
\hline Mean \pm SD & \multicolumn{2}{|c|}{$31.47 \pm 7.979$} & \multicolumn{2}{|c|}{$38.54 \pm 7.148$} \\
\hline $\mathrm{t}$ & \multicolumn{2}{|c|}{$0.001^{*}$} & & \\
\hline
\end{tabular}

*Significant at $(\mathbf{p}<0.05)$ 
Table (5): Correlation between total knowledge score and total usage score of social media among the studied community health nursing students preprogram and three months post program intervention

\begin{tabular}{|c|c|c|c|c|}
\hline \multirow{3}{*}{ Variables } & \multicolumn{2}{|c|}{$\begin{array}{c}\text { Knowledge about social } \\
\text { network sites }\end{array}$} & \multicolumn{2}{|c|}{ Usage of social network sites } \\
\hline & $\begin{array}{l}\text { Pre - } \\
\text { intervention }\end{array}$ & $\begin{array}{l}\text { Three months } \\
\text { post } \\
\text { intervention }\end{array}$ & $\begin{array}{l}\text { Pre - } \\
\text { intervention }\end{array}$ & $\begin{array}{l}\text { Three months } \\
\text { post } \\
\text { intervention }\end{array}$ \\
\hline & $\mathrm{r}$ & $\begin{array}{l}\mathrm{r} \\
\mathrm{P}\end{array}$ & $\mathrm{r}$ & $\begin{array}{l}\mathrm{r} \\
\mathrm{P}\end{array}$ \\
\hline $\begin{array}{l}\text { Pre total knowledge score } \\
\text { of social network sites }\end{array}$ & - & $\begin{array}{l}-0.265 \\
0.018^{*}\end{array}$ & $\begin{array}{l}0.252 \\
0.025^{*}\end{array}$ & $\begin{array}{c}-0.026 \\
0.821\end{array}$ \\
\hline $\begin{array}{l}\text { Post total knowledge } \\
\text { score of social network } \\
\text { sites }\end{array}$ & $\begin{array}{l}-0.265 \\
0.018^{*}\end{array}$ & - & $\begin{array}{c}-0.035 \\
0.761\end{array}$ & $\begin{array}{c}0.391 \\
0.000^{* *}\end{array}$ \\
\hline $\begin{array}{l}\text { Pre total usage score of } \\
\text { social network sites }\end{array}$ & $\begin{array}{l}0.252 \\
0.025^{*}\end{array}$ & $\begin{array}{c}-0.035 \\
0.761\end{array}$ & - & $\begin{array}{c}-0.010 \\
0.929\end{array}$ \\
\hline
\end{tabular}


Table (6): Relationship between levels of knowledge of social network sites of the studied community health nursing students during preprogram intervention and history of using social network sites

\begin{tabular}{|c|c|c|c|c|c|c|c|}
\hline \multirow[t]{3}{*}{ History of using social network sites } & \multicolumn{7}{|c|}{$\begin{array}{c}\text { Levels of knowledge about social network } \\
\text { sites during preprogram }\end{array}$} \\
\hline & \multicolumn{2}{|c|}{$\begin{array}{c}\text { Poor } \\
\text { knowledge } \\
\mathbf{n}=(\mathbf{5 1})\end{array}$} & \multicolumn{2}{|c|}{$\begin{array}{c}\text { Fair } \\
\text { knowledge } \\
\mathbf{n}=(\mathbf{1 6})\end{array}$} & \multicolumn{2}{|c|}{$\begin{array}{c}\text { Good } \\
\text { knowledge } \\
\text { n=(12) }\end{array}$} & \multirow{2}{*}{$\begin{array}{l}\mathbf{X}^{2} \\
\mathbf{p}\end{array}$} \\
\hline & $\mathrm{n}$ & $\%$ & $\mathrm{n}$ & $\%$ & $\mathrm{n}$ & $\%$ & \\
\hline $\begin{array}{l}\text { Period of using social networking } \\
\text { sites } \\
\text { Less than } 6 \text { months } \\
6 \text { month } 1<\text { year } \\
1 \text { yr-5 years } \\
\text { More than } 5 \text { years }\end{array}$ & 14 & $\begin{array}{l}15.7 \\
17.6 \\
39.2 \\
27.5\end{array}$ & $\begin{array}{l}7 \\
3 \\
6\end{array}$ & $\begin{array}{l}0.0 \\
43.7 \\
18.8 \\
37.5\end{array}$ & $\begin{array}{l}4 \\
5\end{array}$ & $\begin{array}{c}16.7 \\
8.3 \\
33.3 \\
41.7\end{array}$ & $\begin{array}{l}9.880 \\
0.130\end{array}$ \\
\hline $\begin{array}{l}\text { Hours spend on social networks } \\
\text { sites daily } \\
\text { From one to less than two hours } \\
\text { From two to less than five hours } \\
\text { From five to eight hours } \\
\text { More than } 8 \text { hours }\end{array}$ & 23 & $\begin{array}{l}45.0 \\
11.8 \\
11.8\end{array}$ & $\begin{array}{l}3 \\
6\end{array}$ & $\begin{array}{l}43.7 \\
18.8 \\
37.7 \\
0.0\end{array}$ & $\begin{array}{l}7 \\
0 \\
3\end{array}$ & $\begin{array}{l}16.7 \\
58.3 \\
0.0 \\
25.0\end{array}$ & $\begin{array}{c}15.785 \\
0.01^{*}\end{array}$ \\
\hline
\end{tabular}

*Significant at $(\mathbf{p}<0.05)$ 
Table (7): Relationship between levels of usage of social network sites of the studied community health nursing students during preprogram intervention and history of using social network sites

\begin{tabular}{|c|c|c|c|c|c|c|c|}
\hline \multirow[t]{3}{*}{ History of using social network sites } & \multicolumn{7}{|c|}{$\begin{array}{c}\text { Levels of usage of social network sites } \\
\text { during preprogram }\end{array}$} \\
\hline & \multicolumn{2}{|c|}{$\begin{array}{c}\text { Poor } \\
\text { usage } \\
\mathbf{n}=(\mathbf{1 1})\end{array}$} & \multicolumn{2}{|c|}{$\begin{array}{c}\text { Moderate } \\
\text { usage } \\
\mathbf{n}=(\mathbf{3 9})\end{array}$} & \multicolumn{2}{|c|}{$\begin{array}{c}\text { Good } \\
\text { usage } \\
\text { n =(29) }\end{array}$} & \multirow{2}{*}{$\begin{array}{r}\mathbf{X}^{2} \\
\mathbf{p}\end{array}$} \\
\hline & $\mathrm{N}$ & $\%$ & $\mathrm{n}$ & $\%$ & $\mathrm{n}$ & $\%$ & \\
\hline $\begin{array}{l}\text { Period of using social networking sites } \\
\text { Less than } 6 \text { months } \\
6 \text { month } 1<\text { year } \\
1 \text { yr-5 years } \\
\text { More than } 5 \text { years }\end{array}$ & $\begin{array}{l}6 \\
3\end{array}$ & $\begin{array}{l}9.1 \\
9.1 \\
54.5 \\
27.3\end{array}$ & $\begin{array}{l}9 \\
13 \\
12\end{array}$ & $\begin{array}{l}12.8 \\
23.1 \\
33.3 \\
30.8\end{array}$ & $\begin{array}{l}8 \\
10\end{array}$ & $\begin{array}{l}13.8 \\
24.1 \\
27.6 \\
34.5\end{array}$ & $\begin{array}{l}2.929 \\
0.818\end{array}$ \\
\hline $\begin{array}{l}\text { Hours spend on social networks sites } \\
\text { daily } \\
\text { From one to less than two hours } \\
\text { From two to less than five hours } \\
\text { From five to eight hours } \\
\text { More than } 8 \text { hours }\end{array}$ & $\begin{array}{l}2 \\
2 \\
4\end{array}$ & $\begin{array}{l}18.2 \\
18.2 \\
36.3\end{array}$ & $\begin{array}{l}14 \\
4\end{array}$ & $\begin{array}{l}43.6 \\
35.9 \\
10.5 \\
10.5\end{array}$ & $\begin{array}{l}17 \\
6\end{array}$ & $\begin{array}{l}58.6 \\
20.7 \\
3.4\end{array}$ & $\begin{array}{c}16.423 \\
0.01^{*}\end{array}$ \\
\hline
\end{tabular}

${ }^{*}$ Significant at $(\mathbf{p}<0.05)$ 


\section{levels of knowledge of the studied community health nursing students}

pre program three months post program

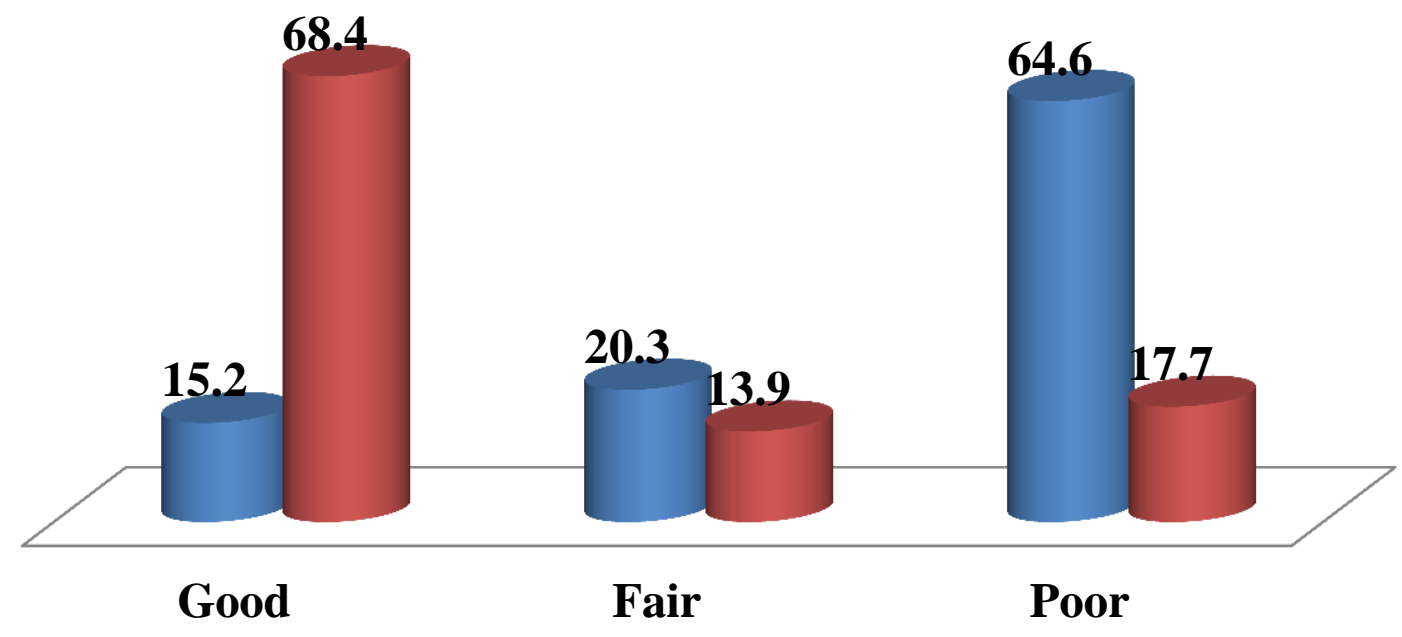

Figure (1):Levels of knowledge of the studied community health nursing students about social network sites pre and three months post program intervention 


\section{Discussion}

Social network sites (SNS) provide people with more and easiest information. This may result in changing in the learning, interactive and sharing environment. SNS have become the most popular form of online conversation; it has changed the online world in the last ten years dramatically. It allow all people either young or old to communicate, interact and sharing information, ideas, feelings with each other's ${ }^{(22,23)}$.

As a result of increased SNS popularly, experts and professors believe that the use of social network sites may affect positively or negatively on educational performance of students. So that, the community health nurse plays an important role in assessment of students` knowledge about social network sites, provides them with suitable information about available social network sites, teaching them the proper uses, correct and suitable duration of time for using social network sites ${ }^{(24)}$. Therefore, this study aims to evaluate the effect of educational program on knowledge and uses of social network sites among community health nursing students on Faculty of Nursing at Tanta University. Communicating in person- to- person situation is quite different from communicating through the internet and SNS. Through these websites: messages, updating status and chatting are considered methods of communication with friends. The sites open up various portals through which persons get information and create more different news outlets ${ }^{(25)}$.

The current study revealed that the majority of the studied community health nursing were using social network sites and WhatsApp was the most frequently used method Table (2). This may be due to that community health nursing students believe that Whats app is the easiest, fastest and most popular method of social network sites for them. This is in line with the results of the studies conducted by Siahiet al. (2018) and Perpetua and Kelechi (2018), who found that using social network sites and WhatsApp was the most frequently used method among the studied students of Alvan Ikoku Federal College of Education in Owerri ${ }^{(26,27)}$.

Regarding number of hours spent on social media daily. Experts have recommended 30 minutes or less per day as the maximum time a person should spend on social media. It can be used on academic education to solve academic problem, research work, for online academic group discussion. For collaborative learning (28), also, it can be used for socialization, entertainments and informativeness. 
The current study showed that about onethird of the studied students were spending from $1<2$ hours on social networks daily (Table 2). This may be related to during the use of social network sites persons don't aware of time and spent most of time transferring from chatting to communicating to searching and at the end most time lost without awareness of it and this mean that they don't have control and management of their times. This is consistent with Lusk (2010), who studied the Effect of Social Media on the Study Habits of Students of Alvan Ikoku Federal College of Education in Owerri and found that most of the students were using social media extensively (more than one hour per day) ${ }^{(29)}$.

Social network sites have greater effect on our ordinary social relation, where face to face communication decreased or become lost. As a result of it different methods of communication and interaction were used on social media. Also social network sites affect greatly in different sides of life as in education, work and investment ${ }^{(30,31)}$.

One of the most important results of the present study were the improvement of the knowledge of the studied community health nursing students regarding meaning, causes, positive effect, negative effect, advantages and dis advantages of using social network sites from preprogram to three months post program intervention with a statistically significant difference between them (table 3 ). This may be due to that the educational program was effective in improving knowledge of the studied community health nursing students about social network sites. This similarlywith Ahmed et al. (2011), in Oman, who stated that there was significant improvement of the knowledge of the studied students from preprogram to three months post program intervention with a statistically significant difference between them ${ }^{(32)}$.

Social media is considered a double-edged sword when a person uses it well, helps advance work, education and benefits all aspects of life. On the other hand when person misuse it, it affect badly in health, performance and also decrease motivational levels especially among students as they depend greatly on easily accessible information ${ }^{(33,34)}$.

The current study illustrated that, there was a significant improvement of the total usage score of social network sites by the studied community health nursing students from preprogram to three- months post program intervention (Table 4). This related to the effectiveness of the educational program in improving the studied community health nursing students' usage of social network sites. 
This is in line with the results of the studies conducted by Siahi et al. (2018), who found that there was a significant improvement of the total usage score of social network sites by the studied students from preprogram to three- months post program intervention ${ }^{(26)}$.

Furthermore, the current study showed that there was a significant negative correlation between total knowledge score pre and three-months post program intervention. While, total knowledge score preprogram was a positively correlated with total usage score of social network sites preprogram. Moreover, post total knowledge score was a positively correlated with post total usage score. Because it is normally that during preprogram, the community health nursing students had low level of knowledge about social network sites and this levels increased post program as a result of program implementation. While as the total knowledge increases, the total usage of social network sites will in turn improves as well ${ }^{(35-37)}$.

Finally, health education is a vital part of nursing care, especially when used comprehensive assessment that target all aspects of the problem and factors that support improvement. So that, the community health nurse plays an important role in assessment of students` knowledge about social network sites, provides them with suitable information about available social network sites, teaching them the proper uses, correct and suitable duration of time for using social network sites ${ }^{(38-40)}$.

\section{Conclusion}

Based on the results of the current research, it was noticed thatthe educational program was effective in improving level of knowledge and uses of the studied sample toward social network sites. In which before program application, the majority of studied sample had poor knowledge and uses scores. While, after program application,the majority of them had good total knowledge and usage scores.There was statistically significant difference between hours spends on social network sites daily by community health nursing students and levels of knowledge preprogram. There was a significant improvement of the total usage score of social network sites by the studied community health nursing students from preprogram to three- months post program intervention.

\section{Recommendation}

The following recommendations can be suggested based on the results of the present study:

1. Conducting lectures, workshops and campaigns to raise awareness about correct, complete and accurate information on social network sites 
and its uses among other students and all community groups.

2. Group discussions, Seminars and symposiums should be arranged at regular interval to train students how to make control over time when using social network sites.

3. Conducting Workshops to students about most beneficial sites to their academic education.

4. All possible forms of mass media such as (T.V, newspaper, radio, Posters, and booklets) are needed to help in the dissemination of correct and accurate information to a large sector of the community especially youth about social network sites and its uses.

\section{References}

1. Comerford K, Hager L, Krik K, OsheaJ,Ruhf L. The potential implication of social network in nursing education reveals. $2^{\text {nd }}$ Ed. China: Wollters Kluwer/ Lippincott Williams \&Wilkins Co.; 2012. 92-94.

2. Chang S, Tung F. An empirical investigation of students' behavioural intentions to use the online learning course websites. British Journal of Educational Technology. 2010; 39(1): 71- 83 .

3. Crittenden V, Crittenden W. Digital and social media marketing in business education: Implications for the marketing curriculum. Journal of Marketing Education. 2015; 37(2):715.

4. As a functional definition, social media, 2021. Available at: http://www.forwiki.ro/index.php?title $=$ Special:Pdfprint\&page=Future_of_S ocial_Media

5. Fife E, Nelson C, Clarke T. Online technological media in the higher education classroom: An exploratory investigation of varied levels of Twitter use. International Journal of Online Pedagogy and Course Design. 2014; 4(2): 35-45.

6. Friesen $\mathrm{N}$, Lowe $\mathrm{S}$. The questionable promise of social media for education: Connective learning and the commercial imperative. Journal of Computer Assisted Learning. 2016; 28(3):183- 94.

7. Grosseck G. To use or not to use web 2.0 in higher education? Procedia Social and Behavioral Sciences. 2019; $1(1): 478-82$.

8. Stocking G, Sumida N. Social Media Bots Draw Public's Attention and Concern. 2018. Available at:https://tinyurl.com/ybabbeu4.

9. Wagner K, Oculus G. The virtual reality headset Facebook hopes will bring VR to the mainstream, is finally here. Retrieved 2019; Available at: 
https://tinyurl.com/ycnz468q.

10. Wagner $\mathrm{K}$, Mark Z. In His Own Words, on why AR is Facebook's next big platform bet. 2017; Available at: https://tinyurl.com/yagf24e4.

11. Lampe C,Wohn D Y, Vitak J, Ellison N, Wash R. Student use of Facebook for organizing collaborative classroom activities. International Journal of Computer-Supported Collaborative Learning. 2011; 6(3):329- 47.

12. Liu M, McKelroy E, Kang J, Harron J, Liu S. Examining the Use of Facebook and Twitter as an Additional Social Space in a MOOC. American Journal of Distance Education. 2016; 30(1):14-26.

13. Neier S, Zayer L. Students' perceptions and experiences of social media in higher education. Journal of Marketing Education. 2015; 37(3): 133-43.

14. Mazer P, Murphy E, Simonds J. I'll See You On "Facebook": The Effects of Computer-Mediated Teacher SelfDisclosure on Student Motivation, Affective Learning, and Classroom Climate. Communication Education, 2017; 56(1): 1-17.

15. Tucker C. Social networks, personalized advertising and privacy controls. Journal of Marketing

Research. 2014; 51(5):546-62.

16. Means B, Toyama Y, Murphy R, Bakia M, Jones K. Evaluation of Evidence-Based Practices in Online Learning: A Meta-Analysis and Review of Online Learning Studies. US Department of Education Office of Planning, Evaluation, and Policy Development, Policy and Program Studies Service. 2019.Available at:http://files.eric.ed.gov/fulltext/ED50 5824.pdf.

17. Smith S D, Caruso J B. The Studyof Undergraduate Students and Information Technology. Educause Center for Applied Research. 2016. available at: https://library.educause.edu/ /media/fi les/library/2010/10/ers1006w-pdf.pdf.

18. Disadvantage of social networking sites. 2020. Available at: https://www.activehealth.sg/read/scree n-time/what-are-the-negative-sideeffects-of-too-much-screen-time

19. Effect of social networking sites. 2019.Available at: https://www.verywellfamily.com/ways -social-media-affects-teen-mentalhealth-4144769

20. Allender A, Rector C, Warner K. Community and Public Health 
Nursing: Theoretical basis for promoting social network uses. $8^{\text {th }}$ ed. Tokyo: Wolters Kluwer/ Lippincott Williams\& Wilkins Co.; 2014. 569-83.

21. Gupta S, Bashir.Social networking usage questionnaire: Development and validation in an Indian higher education context.Turkish Online Journal of Distance Education. 2018; 19(4): 214-222. Available at:https://www.researchgate.net/publicatio n/328365534_Social_Networking_Usage _Questionnaire_Development_and_Valid ation_in_an_Indian_Higher_Education_C ontext

22. Mehmood S, Taswir T. The effects of social networking sites on the academic performance of students in college of applied sciences, Nizwa, Oman. International Journal of Arts and Commerce. 2013; 2(1): 111-25.

23. Langat A., Influence of social media on study habit of undergraduate students in Kenyan Universities. International Journal of Novel research in Humanity and Social Sciences. 2015; 2(4): 42- 55.

24. Asemah S, Okpanachi R, Edegoh L. Influence of social media on the academic performance of undergraduate students of Kogi State University, Anyigba, Nigeria.
Research on Humanities and Social Sciences Journal. 2013; 3(12):90-6.

25. Amin Z, Mansoor A, Hussain S, Hashmat F. Impact of Social Media on Students academic Performance. International Journal of Business and Management Invention. 2016; 5 (4):22-9.

26. Siahi E, Maiyo K. Study of the relationship between study habits and academic achievement of students: Amongst Students, of AlvanIkoku Federal College of Education in Owerri. International Journal of Educational Administration and Policy Studies. 2018; 7(7): 134-41.

27. Perpetua OE, Kelechi EE. Effect of social media on the study habits of students of Alvan Ikoku federal college of education, Owerri. International Journal of Educational and Pedagogical Sciences. 2018; 12(1): 220-224. Available at:Effect of Social Media on the Study Habits of Students of AlvanIkoku Federal College of Education, Owerri (waset.org)

28. Westerman D, Daniel S, Bowman N. Learned risks and experiences rewards: Exploring the potential sources of students' attitudes toward social media and face-to-face 
communication. Internet and Higher

Education Journal. 2016; 31(1): 52-7.

Available

at:https://doi.org/10.1016/j.iheduc.201

6.06 .004 .

29. Lusk, B. Effect of social media on the study habits of students of Alvan Ikoku Federal College of education in Owerri. International Journal of Educational Administration and Policy Studies. 2010; 7(9): 144-51.

30. Tan J. Social network: A mixed methods study of students' engagement with a school-based Web 2.0 learning innovation. Thesis, Queensland University of Technology, Brisbane.

Available at:http://eprints.qut.edu.au/30396/

31. Neier S, Zayer L. Students' perceptions and experiences of social media in higher education. Journal of Marketing Education. 2016; 37(3): 133-43.

32. Ahmed I, Qazi T. A look out for academic impacts of social networking sites (SNSs): A student based perspective, in Oman. African Journal of Business Management. 2011; 5(12): 5022-31.

33. McKelroy E, Kang J, Harron J, Liu S. Examining the use of facebook and twitter as an additional social space.
American Journal of Distance Education. 2016; 30(1): 14-26.

34. Mazer P, Murphy E, Simonds J. The effects of computer-mediated teacher self-disclosure on student motivation, affective learning, and classroom climate. Communication Education Journal. 2020;56(1): 1-17.

35. Kietzmann H, Hermkens K, McCarthy I, Silvestre B. Social media? Get serious! Understanding the functional building blocks of social media. Business Horizons, 2015; 54(3): 241- 51.

36. Lackovic N, Kerry R, Lowe R, Lowe T. Being knowledge, power and profession subordinates: Students' perceptions of Twitter for learning. The Internet and Higher Education Journal. 2017; 1(1): 41-8.

37. MehMood S, Taswir T. The effect of social networking site on the Academic Performance on students in college of applies sciences, Nizwa, Oman. International Journal of Arts and Commence.2015; 2 (1): 111-23.

38. Allender A, Rector C, Warner $\mathrm{K}$. Community and Public Health Nursing: Theoretical basis for promoting social network uses. $8^{\text {th }}$ ed. Tokyo: Wolters Kluwer/ Lippincott Williams\& Wilkins Co.; 2016. 569-83.

39. Clark M. Community Health Nursing: Advocacy for Population Health. $5^{\text {th }}$ 
ed. United States: Pearson Education; 2017.

124.Available

at:https://www.pearson.com/us/highereducation.html?mcid=pc. 1028

40. Vangelisti A. The Routledge Community Health Nursing Handbook of Family Communication: Psychology Press. Lawrence Erlbaum Associates: Mahwah, New Jersey; 2015. 20-30. Available at: http://komunikasi.unsoed.ac.id/sites/de fault/files/handbook\%20of\%20family $\% 20$ communication.pdf 